\title{
A Causal Relationship between Trade, Foreign Direct Investment and Economic Growth in Greece
}

\author{
Melina Dritsaki, Chaido Dritsaki and Antonios Adamopoulos \\ Department of Applied Informatics, \\ University of Macedonia Economics and Social Sciences, Greece
}

\begin{abstract}
This study investigates the relationship between Trade, Foreign Direct Investment (FDI) and economic growth in Greece over the period 1960-2002. The cointegration analysis suggested that there is a long-run equilibrium relationship. The results of the Granger causality test showed that there is a causal relationship between the examined variables. Economic growth, trade and FDI appear to be mutually reinforcing under the open-door policy.
\end{abstract}

Key words: Trade, Foreign Direct Investment, Economic Growth, Granger Causality

\section{INTRODUCTION}

The role of trade policy on economic growth has been the focus of considerable academic effort. Openness, namely the sum of exports and imports of Gross Domestic Product (GDP), has been considered one of the main determinants of economic growth. Export-led growth postulates that exports consist the principal channel through which the liberalization process can affect the output level and eventually the rate of economic growth.

Export expansion can increase productivity offering greater economies of scale $^{[1]}$. Moreover, exports are likely to alleviate foreign exchange constraints and can thereby provide greater access to international markets ${ }^{[2]}$. Endogenous growth theory emphasizes the role of exports on economic growth highlighting that exports can increase long-run growth by allowing innovations growth in sectors of research and development ${ }^{[3,4,5,6]}$.

Nevertheless, the results obtained by empirical studies, which recently have applied causality tests to examine the nature of a causal relationship between exports and economic growths are also mixed. Although some studies have found a positive association, others resulted in reverse conclusions. It is not clear in the literature to what degree is the positive relation between trade and growth due to the fact that trade is stimulative of growth and to what degree does it reflect the fact that growth leads to trade. The rate of economic growth differs from country to country, technological advance increases slowly or rapidly relative to the economic structure of each country, while when the monetary and the fiscal policy are not taking account of, they have a negative effect on economic growth ${ }^{[7]}$.

Found a negative relation between exports and growth. This conclusion may be due to the nonexistence of a linear relationship between openness and economic growth. According to ${ }^{[8]}$ Granger causality testing procedure is not satisfactory as it can lead to severe over-rejection of a non-causal null hypothesis leafing pen the possibility of distortions in the final inference process. To avoid these preliminary tests ${ }^{[9,10]}$ proposes a technique that it is applicable irrespective of the integration or cointegration of the examined variables in a multivariate model.

Moreover, assuming that trade does induce economic growth, a question should arise if there are some other factors, which affect this relationship. Indeed, trade liberalization can cause not only trade expansion but also the increase of foreign direct investment in one country.

The best interpretation of the empirical relationship between openness and economic growth should contribute not only to the understanding of the role of foreign direct investments to economic growth but also should facilitate the interpretation of the relationship between trade and foreign direct investments.

There is an increasing agreement both among developed and developing countries about the types of benefits, which are likely to accrue to the host economy from FDI. This is particularly the case for technology and management expertise as multinational enterprises seem to be one of the principal vehicles for the international transfer of technology.

The link between technology and economic growth has been highlighted by an OECD study of both OECD and developing countries, which have found a significant effect on economic growth from the innovation and diffusion of technology ${ }^{[11]}$. Furthermore, foreign direct investments can contribute to economic growth because they tend to be more productive than the investments of local firms. Another mechanism through which foreign direct investments can affect economic growth is the generation of productivity spillovers $^{[12,13]}$.

Find evidence that foreign direct investments have led to significant positive spillover effects on 
the labor productivity of domestic firms and on the rate of productivity growth in Mexico ${ }^{[14]}$. ${ }^{[15,16]}$ argues that this effect may arise from a process of competitive interaction between foreign and domestic firms where the technological gap is quite great.

However, the effect of foreign direct investments in economic growth is an empirical question as it seems to be dependent upon a set of conditions in the host country's economy. The beneficial impact of foreign direct investment is enhanced in an environment characterized by an open trade regime and macroeconomic stability. In this environment foreign direct investments can play a key role in improving the capacity of the host country to respond to the opportunities offered by the global economic integration ${ }^{[17]}$.

${ }^{[18]}$ examining the empirical relationship between economic growth and foreign direct investments, found that there is a unidirectional causal relationship between FDI inflows as a percentage of GDP and the growth of per capita GDP in all developed countries over the period 1960-1985.

${ }^{[19]}$ highlight that a positive relationship between foreign direct investments flows and economic growth is dependent on the achievement of a minimum threshold of human capital.

Generally, trade liberalization and export growth consist the main target for economic restructuring. The abolition of tariff barriers allows foreign direct investment growth in the domestic market of a developed economy ${ }^{[20]}$.

Data and specification of the model: In this study the method of vector autoregressive model (VAR) is adopted to estimate the causal relationship between exports, economic growth and foreign direct investments which has the following form:

$\mathrm{EXP}=\mathrm{f}(\mathrm{GDP}, \mathrm{FDI})$

Where:

$\mathrm{EXP}=$ Exports

GDP $=$ Gross domestic product

FDI $=$ Foreign direct investments

The variable of economic growth (GDP) is measured by the real GDP. The variable of FDI is measured by the foreign direct investments flows. The variable of exports is measured by the real revenues from exports. The data that are used in this analysis are annual, covering the period 1960-2002 and are obtained from the International Monetary Fund ${ }^{[21]}$.
All data are expressed in logarithms in order to include the proliferative effect of time series and are symbolized by the letter $\mathrm{L}$ preceding each variable name. If these variables share a common stochastic trend and their first differences are stationary, then they can be cointegrated.

Also, the use of 1 st differences in econometric studies facilitates the results interpretation, since the first differences of logarithms of initial variables represent the rate of change of these variables ${ }^{[22]}$.

Economic theory scarcely provides some guidance for which variables appear to have a stochastic trend and when these trends are common among the examined variables as well. For the analysis of the multivariate time series that include stochastic trends, the Augmented ${ }^{[23]}$ (ADF) unit root test is used for the estimation of individual time series with the intention to provide evidence about when the variables are integrated. This is followed by multivariate cointegration analysis.

Unit root test: The cointegration test among the variables that are used in the above model requires previously the test for the existence of unit root for each variable and especially for Gross Domestic Product (GDP), exports, foreign direct investment, using the Augmented $^{[23]}$ test on the following regression:

$\Delta \mathrm{X}_{\mathrm{t}}=\delta_{0}+\delta_{1} \mathrm{t}+\delta_{2} \mathrm{X}_{\mathrm{t}-1}+\sum_{\mathrm{i}=1}^{\mathrm{k}} \alpha_{\mathrm{i}} \Delta \mathrm{X}_{\mathrm{t}-\mathrm{i}}+\mathrm{u}_{\mathrm{t}}$

The ADF regression tests for the existence of unit root of $X_{t}$, namely in the logarithm of all model variables at time $\mathrm{t}$. The variable $\Delta \mathrm{X}_{\mathrm{t}-\mathrm{i}}$ expresses the first differences with $\mathrm{k}$ lags and final $\mathrm{u}_{\mathrm{t}}$ is the variable that adjusts the errors of autocorrelation. The coefficients $\delta_{0}, \delta_{1}, \delta_{2}$ and $\alpha_{i}$ are being estimated. The null and the alternative hypothesis for the existence of a unit root in variable $\mathrm{X}_{\mathrm{t}}$ is:

$\mathrm{H}_{\mathrm{o}}: \delta_{2}=0 \quad \mathrm{H}_{\mathrm{e}}: \delta_{2}<0$

The results of these tests appear in Table 1 . The minimum values of the Akaike ${ }^{[24]}$ (AIC) and Schwartz (SC) statistics have provided the better structure of the ADF equations as well as the relative amount of time lags, under the indication "Lag". As far as the autocorrelation disturbance term test is concerned, the Lagrange Multiplier LM (1) test has been used. The ${ }^{[25]}$ econometric package that was used for the estimation of ADF test, provides us the simulated critical values. 
Table 1: DF/ADF Unit Root Tests

\begin{tabular}{|c|c|c|c|c|c|c|}
\hline \multirow[b]{2}{*}{ Variables } & \multirow[b]{2}{*}{ Lag } & \multicolumn{2}{|l|}{ In their levels } & & \multicolumn{2}{|l|}{$1^{\text {st }}$ differences } \\
\hline & & $\begin{array}{l}\text { Test statistic } \\
\text { (DF/ADF) }\end{array}$ & $\mathrm{LM}(1)$ & & $\begin{array}{l}\text { Test statistic } \\
\text { (DF/ADF) }\end{array}$ & LM(1) \\
\hline$\overline{\text { LEXP }}$ & 1 & -1.2782 & $\begin{array}{l}4.1861 \\
{[0.041]}\end{array}$ & 0 & -7.4643 & $\begin{array}{l}2.0688 \\
{[0.150]}\end{array}$ \\
\hline LGDP & 1 & -1.0101 & $\begin{array}{l}0.7322 \\
{[0.392]}\end{array}$ & 1 & -4.1375 & $\begin{array}{l}0.90413 \\
{[0.342]}\end{array}$ \\
\hline LFDI & 0 & -2.3438 & $\begin{array}{l}2.5322 \\
{[0.112]}\end{array}$ & 0 & -5.8463 & $\begin{array}{l}0.7242 \\
{[0.697]}\end{array}$ \\
\hline
\end{tabular}

Critical value: -3.4547

$\hat{\lambda}_{1}=0.86390 \quad \hat{\lambda}_{2}=0.30935 \quad \hat{\lambda}_{3}=0.01707$

Table 2: Johansen and Juselious Cointegration Tests Variables LEXP, LGDP, LFDI Maximum lag in VAR = 3

\begin{tabular}{|c|c|c|c|c|}
\hline \multirow{2}{*}{$\begin{array}{l}\text { Eigenvalues } \\
\text { Null }\end{array}$} & \multirow[b]{2}{*}{ Alternative } & \multirow[b]{2}{*}{ Eigenvalue } & \multicolumn{2}{|c|}{ Critical Values } \\
\hline & & & $95 \%$ & $90 \%$ \\
\hline $\bar{r}=0$ & $\mathrm{r}=1$ & 79.7752 & 17.6800 & 15.5700 \\
\hline $\mathrm{r}<=1$ & $r=2$ & 14.8050 & 11.0300 & 9.2800 \\
\hline $\mathrm{r}<=2$ & $r=3$ & 0.6887 & 4.1600 & 3.0400 \\
\hline \multicolumn{5}{|l|}{ Trace Statistic } \\
\hline$r=0$ & $\mathrm{r}>=1$ & 95.2685 & 24.0500 & 21.4600 \\
\hline $\mathrm{r}<=1$ & $\mathrm{r}>=2$ & 15.4937 & 12.3600 & 10.2500 \\
\hline $\mathrm{r}<=2$ & $r=3$ & 0.6887 & 4.1600 & 3.0400 \\
\hline
\end{tabular}

The results of Table 1 suggest that the null hypothesis of a unit root in the time series cannot be rejected at a 5\% level of significance in varying levels. Therefore, no time series appear to be stationary in varying levels. However, when the logarithms of the time series are transformed into their first differences, they become stationary and consequently the related variables can be characterized integrated of order one, I (1). Moreover, for all variables the LM (1) test first differences show that there is no correlation in the disturbance terms.

Cointegration and Johansen Test: Since it has been determined that the variables under examination are integrated of order 1 , the cointegration test is performed. The testing hypothesis is the null of noncointegration against the alternative that is the existence of cointegration using the ${ }^{[26]}$ maximum likelihood procedure ${ }^{[27,28]}$. An autoregressive coefficient is used for the modeling of each variable (that is regarded as endogenous) as a function of all lagged endogenous variables of the model.

Given the fact that in order to apply the Johansen technique a sufficient number of time lags is required, we have followed the relative procedure, which is based on the calculation LR (Likelihood Ratio) test statistic $^{[29]}$. The results showed that the value $\rho=3$ is the appropriate specification of the above relationship. Further on we determine the cointegration vectors of the model, under the condition that matrix $\Pi$ has an order $r<n(n=4)$. The procedure of calculating order $\mathrm{r}$ is related to the estimation of the characteristic roots (eigenvalues), which are the following:
The results that appear in Table 2 suggest that the number of statistically significant cointegration vectors is equal to 2 and is the following:

$$
\begin{aligned}
& \text { LEXP }=1.1260 \text { LGDP }+0.031599 \text { LFDI } \\
& \text { LEXP }=11.5263 \text { LGDP }-16.5262 \text { LFDI }
\end{aligned}
$$

The coefficient estimates in equilibrium relationships, which are essentially the long-run estimated elasticities relative to exports suggest that foreign direct investments are inelastic to exports, while economic growth is elastic to exports.

According to the signs of the vector cointegration components and based on the basis of economic theory the first of the above relationships can be used as an error correction mechanism in a VAR model.

A VAR model with an error correction mechanism: After determining that the logarithms of the model variables are cointegrated, we must estimate then a VAR model in which we shall include a mechanism of Error Correction Model (MEC). The error correction model arises from the long-run cointegration relationship and has the following form:

$$
\begin{aligned}
& \text { DLEXPG }_{\mathrm{t}}=\text { lagged (DLEXPG, DLGDPN } \\
& \left.\mathrm{t}, \text { DLFDIG }_{\mathrm{t}}\right) \\
& +\mathrm{lu}_{\mathrm{t}-1}+\mathrm{V}_{\mathrm{t}}
\end{aligned}
$$

where, $\Delta$ is reported to first differences of variables $\mathrm{u}_{\mathrm{t}-1}$ are the estimated residuals from the cointegrated regression (long-run relationship) and represents the deviation from the equilibrium in time period $t$. 
American J. Appl. Sci., 1 (3), 230-235, 2004

Table 3: Error Correction Model

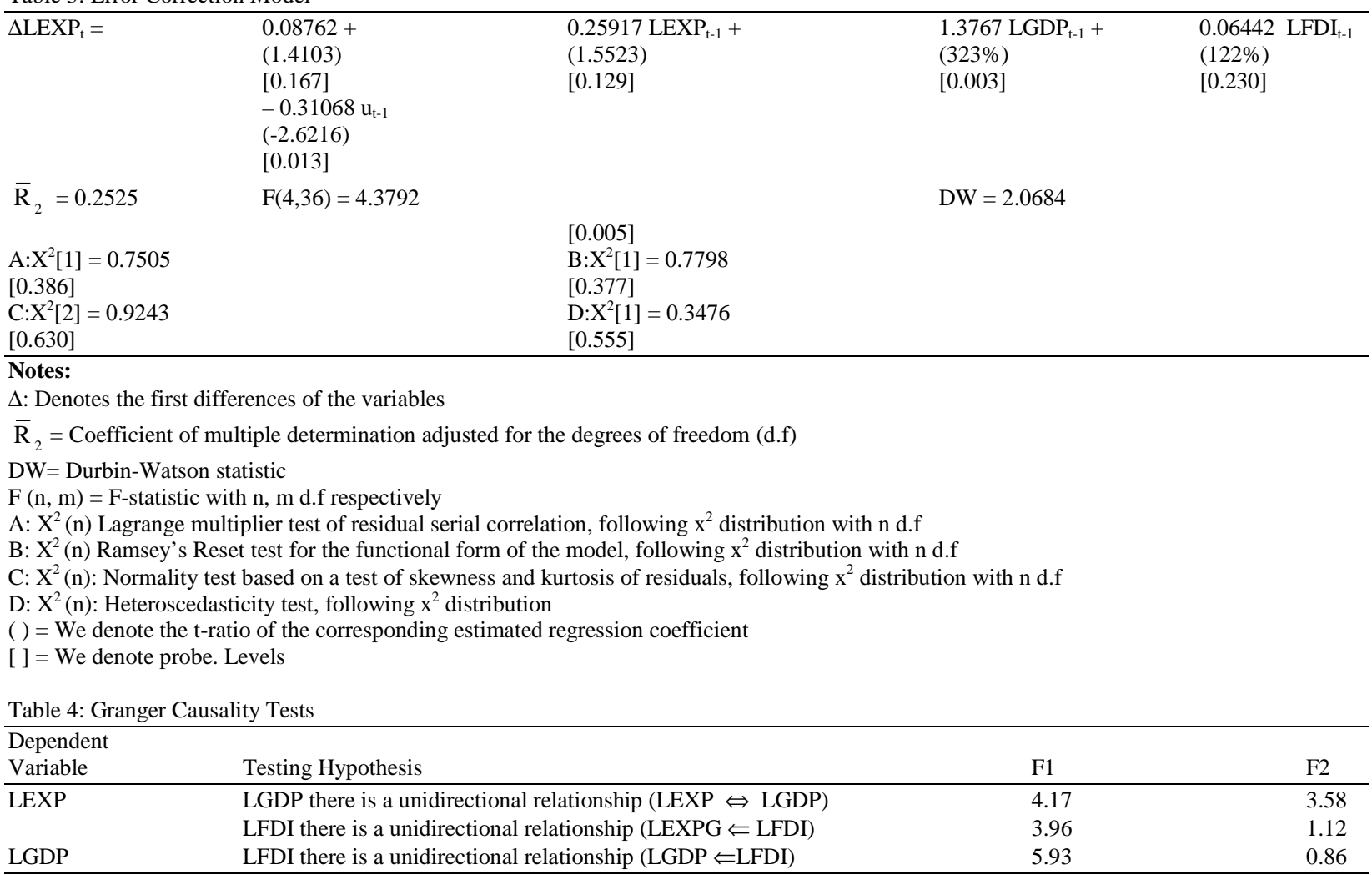

Critical values: 3.07

$-1<\lambda<0$ short-run parameter

$\mathrm{V}_{\mathrm{t}}$ white noise disturbance term

One difficulty, which a researcher faces with the estimation of an autoregressive VAR model, is the appropriate specification of the model. Specially, the researcher has to decide which deterministic components should be included and which number of lags should be used as well.

Since arbitrarily selected specifications of the autoregressive VAR model are possible to produce unreliable results, we use the selection criterion of a database model in order to specify the autoregressive VAR model for the Greek economy. Among the different selection criteria of the model the one that suggested by ${ }^{[30]}$, known as Schwartz Bayesian information criterion, seems to outperform other alternative solutions ${ }^{[31]}$. Therefore the specification of the autoregressive VAR model is based on the Schwartz Bayesian information criterion. Also, the first order specification of the model VAR (1) is selected with a constant and a time trend.

The final form of the Error-Correction Model was selected according to the approach suggested by Hendry ${ }^{[32]}$. The initial order of the time lag for the model is 2 because it is large enough to enclose the system's short-run dynamic. We also apply a number of diagnostic tests on the residuals of the model. We apply the Lagrange test for the residual autocorrelation, the heteroscedasticity test and the Bera-Jarque normality test. We also test the functional form of the model according to the Ramsey's Reset test. The error correction model appears in Table 3.

We do not reject the estimations, which are based on the results of Table 3 according to the statistical and diagnostic tests in 5\% level of significance. The percentage of the total variance of the dependent variable that is described in our model is high enough (25\%). The Error-Correction Term is statistically significant and has a negative sign, which confirms that there isn't any problem in the long-run equilibrium relation between the independent and dependent variables except the variety of foreign direct investment in 5\% level of significance. Their relative price $0.31068(-2.6216)$ denotes a satisfactory convergence rate to an equilibrium point per period.

From the results of Table 3 we can infer that in the long-run an increase of $1 \%$ in GDP will lead to an increase of $1.37 \%$ on exports, while an increase of $1 \%$ in foreign direct investment will lead to an increase of $0.64 \%$ on exports.

Granger causality test: The model was used in order to examine the Granger causal relationships between the variables under examination. As a testing criterion the $\mathrm{F}$ statistic was used. With the $\mathrm{F}$ statistic the hypothesis of the statistic significance of specific groups of explanatory variables was tested for each 
separate function. The results relating to the existence of Granger causal relationships between exports, gross domestic product and foreign direct investments appear in Table $4^{[33]}$.

From the results of Table 4 , there is a bilateral relationship between exports and economic growth, a unidirectional causal relationship between foreign direct investments and economic growth with direction from foreign direct investments to GDP and final there is a unidirectional causal relationship between foreign direct investment and exports with direction from foreign direct investments to exports.

\section{CONCLUSION}

The present study employs with the relationship between exports, economic growth and foreign direct investments using annual data for the period 19602002. The empirical analysis suggested that all variables that used in this study present a unit root. On this basis the Johansen cointegration test analysis was used to lead to a long-run equilibrium relationship among these variables. Then the methodology of error correction model was applied to estimate the short-run and the long-run relationships. The selected cointegrated vector gave the appropriate error correction term, which proved to be negative and statistically significant at a 5\% level of significance during its inclusion in the short-run dynamic equation.

Finally, using Granger causality test we can infer that there is a bilateral causal relationship between exports and economic growth, while there is a unidirectional causal relationship between foreign direct investments and economic growth with direction from foreign direct investments to GDP and also a unidirectional causal relationship between foreign direct investments and exports with direction from foreign direct investments to exports.

\section{REFERENCES}

1. Helpman, E. and P.R. Krugman, 1985. Market Structure and Foreign Trade. Cambridge. MIT Press.

2. Esfahani, H.S., 1991. Exports, Imports and Economic Growth in Semi-Industrialized Countries. J. Development Econ., 35: 93-116.

3. Lucas, R. E., 1988. On the Mechanics of Economic Development. J. Monetary Econ., 22: 3-42.

4. Romer, P.M., 1986. Increasing Returns and Long-Run Growth. J. Political Economy, 94: 1002-37.

5. Romer, P.M., 1989. What Determines the Rate of Growth and Technological Change?, World Bank Working Paper No. 279.
6. Edwards, S., 1992. Trade Orientation, Distortions and Growth in Developing Countries. J. Development Econ. 39: 31-57.

7. Giles, J.A. and C. L. Williams, 2000. Export-led Growth. A Survey of the Empirical Literature and some Non-Causality Results Part 1. J. Int. Trade and Econ. Develop., 9: 261-337.

8. Giles, J.A. and S. Mirza, 1999. Some Protesting Issues in Testing for Granger non-Causality. Mimeo., Dept. Econ., Univ. Victoria.

9. Toda, H.Y. and T.Yamamoto, 1995. Statistical Inference in Vector Autoregressions with Possibly Integrated Processes. J. Econometrics 66: 225-50.

10. Dolado, J.J. and H. Lütkepohl, 1996. Making Wald Tests Work for Cointegrated VAR Systems. Econ. Rev. 15: 369-86.

11. OECD, 1991. Technology and Productivity. The Challenge for Economic Policy, Paris.

12. Blomstoerm, M. and H. Persson, 1983. Foreign Investment and Spillover Efficiency in an Underdeveloped Economy. Evidence from the Mexican Manufacturing Industry, World Development, 11: 493-501.

13. Blomstoerm, M., 1986. Foreign Investment and Productive Efficiency. The Case of Mexico, J. Industrial Econ., 15: 97-110.

14. Blomst_erm, M. and E. Wolf, 1994. Multinational Corporations and Productivity Convergence in Mexico. In W. Baumol, R. Nelson and E. Wolf (Eds.) Convergence of Productivity. CrossNational Studies and Historical Evidence, Oxford. Oxford University Press.

15. Kokko, A., 1994. Technology, Market Characteristics and Spillovers. J. Development Econ., 43: 279-293.

16. Kokko, A., 1996. Productivity spillovers from competition between local firms and foreign affiliates. J. Int. Development 8: 517-530.

17. OECD, 1998. Foreign Direct Investment and Economic Development. Lessons from Six Emerging Economies. Paris.

18. Blomstoerm, M., R. Lipsey and M. Zejan, 1994. What explains the growth of developing countries? Convergence of Productivity, Oxford University Press, Oxford.

19. Borenstein De Gegorio, J. and J. Lee, 1998. How does foreign direct investment affect economic growth? J. Int. Econ., 45: 115-135.

20. Dritsakis, N., 2004. A Causal Relationship Between Inflation and Productivity. An Empirical Approach for Romania, American J. Appl. Sci., 1: 121-128.

21. International Monetary Fund, 2003. Int. Financial Stat. Yearbook, 2003, Washington DC. Various Years.

22. Dritsakis, N., 2003. Hungarian macroeconomic variables-reflection on causal relationships. Acta Oeconomica, 53: 61-73. 
23. Dickey, D.A. and W.A. Fuller, 1979. Distributions of the estimators for Autoregressive time series with a unit root. J. American Stat. Assoc., 74: 427 431.

24. Akaike, H., 1973. Information Theory and an Extension of the Maximum Likelihood Principle. In: Petrov, B. and Csaki, F. (Eds) $2^{\text {nd }}$ International Symposium on Information Theory. Budapest. Akademiai Kiado.

25. MFIT 4.0, 1997. Quantitative Micro Software, Interactive Econometric Analysis. Oxford University Press.

26. Johansen, S., 1988. Statistical analysis of Cointegration Vectors. J. Econ. Dynamics and Control, 12: $231-254$.

27. Johansen, S and K. Juselious, 1990. Maximum Likelihood Estimation and Inference on Cointegration with Applications to the Demand for the Money. Oxford Bulletin of Economics and Statistics, 52: 169-210.
28. Johansen, S. and K. Juselius, 1992. Testing Structural Hypotheses in a Multivariate Cointegration Analysis at the Purchasing Power Parity and the Uncovered Interest Parity for the UK. J. Econometrics, 53: 211-244.

29. Sims, C., 1980. Macroeconomics and Reality. Econometrica, 48: 1-48.

30. Schwarz, R., 1978. Estimating the Dimension of a Model. Annals of Statistics, 6: 461-464.

31. Mills, J. and K. Prasad, 1992. A Comparison of Model Selection Criteria. Econometric Rev., 11: 201-233.

32. Maddala, G.S., 1992. Introduction to Econometrics. 2nd Edition, Prentice Hall, New Jersey.

33. Granger, C. W., 1988. Some Recent Developments in a Concept of Causality. J. Econometrics, 39: 99-211. 